\title{
New York State Labor History Association Annual Conference
}

\section{Robert Wechsler}

Transport Workers Union of America

The New York State Labor History Association is one of the few organizations in the Northeast which regularly brings together academics and practitioners to discuss problems facing workers and their organizations. Historians, economists, and sociologists are called upon to put these issues in an understandable context while trade unionists discuss their current impact on the workplace.

This year's annual conference, held at the headquarters of Local 802 American Federation of Musicians on April 13-14, addressed the topic "Labor's Response to Technology." The program included a labor history and technology walking tour of lower Manhattan led by Debra Bernhardt and Jon Bloom, a screening and discussion of the films "Farewell Etaoin Shrdlu" and "The Business of America" conducted by Miriam Frank, and a full day of conference and discussion.

Historian Robert Asher of the University of Connecticut began the conference with an historical overview of the relationship of labor to technological change in a paper entitled "The Humane View: American Unions and a Century of Technological Change." Asher argued that American workers have a long history of trying to manage technological changes by developing values in the workplace with recognize the right to job security, income stability, and a safe and humane work routine. In countering managements' attempts to control the workplace through Taylor's personnel functions, labor has responded over the past century with its own strategies: calls for government ownership, reduction in hours, strong work rules and work guarantees, unemployment insurance, comanagement, and of course the use of economic action.

Asher concluded that the federal government's inverventionist role from the compromises of the War Labor Board through the present has weakened the workers' role in controlling the introduction of new technology.

The remainder of the morning was reserved for case studies of how specific unions have dealt with technology issues. John Glasel, President of Local 802 American Federation of Musicians, reported on his union's efforts to counter the use of recorded music for dance performances and synthesizers in the production of film scores, television commercials, and jingles. His union has struck over the technology issue and has also lobbied heavily for legislative assistance in changing the copyright codes.

Jack Boris, negotiator for the International Typographical Union, outlined 
the changes in the newspaper industry which began in the 1950s with the introduction of punched paper and the attempt to replace printers with typists. He described the negotiations which resulted in contract language requiring any change in printers' work to remain within the union's jurisdiction. A landmark Sam Kagel arbitration award, however, divided up newspaper work in such a way as to leave only display ads, classified display, and syndicated material in the hands of the printers. Current job holders, suffering a severe decline in work responsibilities, were given lifetime job guarantees.

Debra Bell, Assistant Director for Research and Negoitations at District Council 37, AFSCME, American Federation of State, County, and Municipal Employees, outlined the strategy devised by her union to negotiate new job titles for word processor operators. Finally, Lorraine Giordano, of New York University, critiqued various quality of worklife programs in the workplace.

The afternoon panel was keynoted by Dennis Chamot, Assistant Director of the AFL-CIO Department for Professional Employees. In his paper outlining various policy, collective bargaining, and organizing approaches to the introduction of new technology, Chamot argued that the current trend toward automation is different from those of preceding historical periods. Unlike the industrial revolution where there was relative short-term dislocation, Chamot sees a permanent labor surplus resulting from current technological improvements. He attributed this to the universality of the new technology and the enormous capacity for machinery to replace the worker rather than to reduce his/her skill as in the past.

Chamot suggested a number of alternatives to counter and control these changes including where possible raising the demand for employment security, as opposed to job security. Although critical of Japanese labor-management relationships, he concluded that employment security where it exists forces Japanese managers to innovate actively to create business opportunities which maintain work levels for their employees. Chamot also discussed the Swedish model which trades off some of the increased productivity for such gains as a five week vacation period. The Swedes also maintain a massive government retraining effort. West German and Norweigan examples were also critiqued. Chamot concluded by arguing for more creative legislative and collective efforts along with an organizing campaign which will give unions greater power over these issues.

Regina Canuso, an organizer for District 925, SEIU, Service Employees International Union, described the organizing efforts in the automated offices of Syracuse Equitable, a clerical worksite she likened to a factory. The two issues around which the staff organized were health and safety concerns associated with the use of video display terminals and the introduction of piece work in processing claims on the terminals. Equitable has steadfastly refused to bargain with the unit over a contract and the union retaliated by organizing a boycott asking unions to withdraw pension funds from Equitable and at the same time to pressure the company not to move work out of the state.

Carmine Turchi, representative of the Communication Workers of America, District 1, spoke about his union's response to divestiture and automation at the 
telephone company, and John Knowles, a shop steward representing The Newspaper Guild, reported on the process of negotiating security for members at The New York Times.

Summaries of the conference proceedings will be published in the fall newsletter of The New York State Labor History Association. It is available for the \$5 individual or $\$ 25$ institutional membership to the Association. Write Richard Strassberg, NYSLHA, 150 Ives Hall, Cornell University, Ithaca, NY 14853. Tapes of the proceedings are on deposit at the Robert Wagner Labor Archives at New York University. Contact Debra Bernhardt, Robert Wagner Labor Archives, Tamiment Institute Library, Bobst Library-NYU, 70 Washington Square South, New York, NY 10012. 